\title{
A STUDY OF NON-PERFORMING ASSETS OF ICICI BANK: PRE-MERGER AND POST-MERGER ANALYSIS
}

\author{
Dr.Navneet Joshi* \\ *Professor, Jagan Institute of Management Studies, Sector-5, Rohini, New Delhi -85
}

Sanjive Saxena**

**Associate Professor, Jagan Institute of Management Studies, Sector-5, Rohini, New Delhi -85

Shobha***

*** PGDM-IB,student, Jagan Institute of Management Studies, Sector-5, Rohini, New Delhi -85

Article DOI: https://doi.org/10.36713/epra6374

\begin{abstract}
The purpose of this paper is to examine the impact of mergers and acquisitions (M\&A) of Industrial Credit \& Investment Corporation of India (ICICI Bank) and Bank of Rajasthan on non-performing assets (NPAs) of Industrial Credit \& Investment Corporation of India (ICICI Bank). The analysis consists of two stages. The methodology adopted in the study is based on descriptive research wherein secondary data was collected from the official websites of ICICI bank. By using MS Excel 2016 software, the data was analysed by using the ratio analysis approach, to determine the variation in the current position and secondly, the change in the efficiency of the banks during the pre-merger and post-merger periods by using descriptive statistics in the context of nonperforming assets.
\end{abstract}

KEYWORDS: Non-performing Assets, Merger Acquisition, Pre-merger and Post-merger, CAGR (Compounded Annual Growth Rate), Earning per share.

\section{INTRODUCTION}

A bank is a financial institution that accepts deposit from the public and create demand deposit. It can perform lending activities directly or indirectly through capital markets. Banking evolved in fourteen Century as a modern concept. It made headway in the prosperous cities of Renaissance Italy but in many ways was a continuation of ideas and concepts of credit and lending that had their roots in the ancient world.

Bank is termed as a financial institution works as a mobiliser of funds because it moves money from surplus areas to deficit areas. In general terms banks is a corporation which was authorised by the government to deal with the deposits of money, giving loans to different financially deficit areas and keep investing in government securities. From the economical point of view, a bank helps in the growth of an economy and expansion of the economy by giving loans for investments. With the changing environment, many policies was adopted by financial institutions to survive but the main strategy of financial institutions was merger of banks which 


\section{EPRA International Journal of Research and Development (IJRD)}

helps them to increase their efficiency and profitability.

We have seen that many banks have been already merged to achieve strength economies of scale in India. In 1921, one bank named as Imperial Bank of India was formed after amalgamation of three presidency banks viz. The Bank of Calcutta, The Bank of Madras and The Bank of Bombay afterwards this bank becomes State Bank of India in year 1955. After that many mergers have been done in banking sector just to make them survive.

ICICI bank which was a multinational financial institution head quartered in Mumbai, Maharashtra was established by the name of Industrial Credit and Investment Corporation of India initially in 1995. ICICI bank is the second largest bank in terms of assets and market capitalization having subsidiary in many countries. The bank has a network of 4882 branches and 15101 ATMs across India and has a presence in 17 countries including India. ICICI bank is one of four big Indian Banks which provides many services like Retail banking, corporate banking, investment banking, wealth management, mortgage loans, credit cards, finance and Insurance.

Bank of Rajasthan is a Private banks having 458 offices. It was founded by Late Seth Shri Govind Ram Seksaria (chairman) at Udaipur in 1943, with an initial capital of INR 10 lacs. The Bank was included in the Second Schedule of the Reserve Bank of India in the year 1948. The Bank was among the first banks to introduce the concept of mobile branches, with the opening of its first mobile branch in Jaipur on 5th August, 1960.

ICICI Bank is a strong bank which was merged with the Bank of Rajasthan in 2010 after the approval of boards of both the banks. Under this deal ICICI Bank would give 25 shares for 118 shares (1:4.72) of Bank of Rajasthan. All branches of the Bank of Rajasthan will now function as the branches of the ICICI Bank. Reserve Bank of India approved the deal between both the banks for Rs 3000 crores.

\section{LITERATURE REVIEW}

\begin{tabular}{|c|c|c|c|c|c|}
\hline $\begin{array}{l}\text { S. } \\
\text { No }\end{array}$ & Year & Author & Objective & $\begin{array}{c}\text { Research } \\
\text { Methodology }\end{array}$ & Findings \\
\hline 1. & $\begin{array}{l}\text { Apr- } \\
\text { Jun } \\
2016\end{array}$ & $\begin{array}{c}\text { Dr.Neha } \\
\text { Chabbara } \\
\text { Roy, } \\
\text { Vyshnavi, } \\
\text { Ravikindi } \\
\text { Pushpa, }\end{array}$ & $\begin{array}{l}\text { 1. To find the factors } \\
\text { promoting mergers and } \\
\text { acquisitions in banking } \\
\text { sector. } \\
\text { 2. To do Pre and Post- } \\
\text { merger Valuation on } \\
\text { ICICI Bank and Bank of } \\
\text { Rajasthan. } \\
\text { 3. To forecast } \\
\text { profitability of merged } \\
\text { firm. }\end{array}$ & $\begin{array}{l}\text { Secondary data is } \\
\text { collected from the } \\
\text { Capitaline Database } \\
\text { and RBI database. } \\
\text { Data from 2007-2014 } \\
\text { financial statements } \\
\text { analysis using DCF } \\
\text { techniques. }\end{array}$ & $\begin{array}{l}\text { 1. Improved profitability of } \\
\text { the ICICI bank. } \\
2 \text {. Increased the number of } \\
\text { branches and ATM's and it } \\
\text { has been beneficial for } \\
\text { both the banks. } \\
\text { 3. Share price of Bank of } \\
\text { Rajasthan has appreciated } \\
\text { by } 77 \% \text { but the price of } \\
\text { ICICI fell by } 1.7 \%\end{array}$ \\
\hline 2. & $\begin{array}{l}\text { Jan-Jun } \\
2019\end{array}$ & $\begin{array}{c}\text { Sujit Kumar } \\
\text { Patra, } \\
\text { Ajitabh } \\
\text { Dash }\end{array}$ & $\begin{array}{l}\text { 1. To study the reasons } \\
\text { behind the merger of SBI } \\
\text { with its five associated } \\
\text { banks } \\
2 \text {. To analyse the } \\
\text { employee productivity of } \\
\text { SBI 3. To analyse the } \\
\text { branch productivity of } \\
\text { SBI } \\
4 \text {. To analyse the post- } \\
\text { merger performance of } \\
\text { SBI }\end{array}$ & $\begin{array}{l}\text { 2014-2018 secondary } \\
\text { sources which includes } \\
\text { the Annual Reports of } \\
\text { the SBI } \\
\text { RBI Database Profile of } \\
\text { Banks -various issues; } \\
\text { research publications } \\
\text { (CAGR, T-Test, } \\
\text { Employee \& Branch } \\
\text { Productivity ratios) }\end{array}$ & $\begin{array}{l}\text { 1. The deposits and } \\
\text { advances of SBI post- } \\
\text { merger grew by } 11.92 \% \\
\text { and } 12.54 \% \text { as against } \\
13.22 \% \text { and } 18.97 \% \text {; } \\
\text { profits have recorded a } \\
\text { CAGR of } 1.56 \% \text { as against } \\
\text { pre-merger CAGR of } \\
21.30 \% \text {. } \\
2 . \quad \text { The number of } \\
\text { employees increased by } \\
20 \% \text { during the post- } \\
\text { merger period and its } \\
\text { CAGR was in negative } \\
\text { during the pre-merger } \\
\text { period 3. The number of } \\
\text { branches increased by } \\
4.04 \% \text { as against } 3.17 \text { \% } \\
\text { during the pre-merger }\end{array}$ \\
\hline
\end{tabular}




\section{EPRA International Journal of Research and Development (IJRD)}

Volume: 6 | Issue: 2 | February 2021

- Peer Reviewed Journal

\begin{tabular}{|c|c|c|c|c|c|}
\hline & & & & & period \\
\hline 3. & $\begin{array}{l}\text { Jan } \\
2019\end{array}$ & $\begin{array}{l}\text { Neelam } \\
\text { Tandon, } \\
\text { Deepak } \\
\text { Tandon, } \\
\text { Navneet } \\
\text { Saxena }\end{array}$ & $\begin{array}{l}\text { 1. Analyse the proposed } \\
\text { merger using EPS } \\
\text { method for determining } \\
\text { the advantages of merger } \\
\text { 2. Analyse the balance } \\
\text { sheet of bidder bank pre } \\
\text { and post-merger } \\
\text { 3. Study the advantages } \\
\text { offered by the merger } \\
\text { and the problems related } \\
\text { to the merger. }\end{array}$ & $\begin{array}{l}\text { Earnings per Share } \\
\text { (EPS) method, } \\
\text { Secondary Data, } \\
\text { balance sheets of SBI } \\
\text { have been analysed }\end{array}$ & $\begin{array}{l}\text { No of branches increase, } \\
\text { Post-merger, the total } \\
\text { liabilities of SBI are } \\
\text { expected to rise by } \\
\text { approximately } 26 \% \text {, } \\
\text { whereas the total assets } \\
\text { are expected to rise by } \\
\text { only } 22 \% \text { and the total } \\
\text { profit by } 17 \% \text {, Expensive } \\
\text { Task due to reallocation of } \\
\text { resources. }\end{array}$ \\
\hline 4 & 2016 & $\begin{array}{c}\text { Rao, K.S; } \\
\text { Kumar, K } \\
\text { Phani }\end{array}$ & Case study presentation & $\begin{array}{l}\text { Kotak Mahindra Bank } \\
\text { and ING Vysya Bank }\end{array}$ & \\
\hline 5 & 2018 & $\begin{array}{l}\text { Miss. Anjali } \\
\text { Prava } \\
\text { Mishra } \\
\text { Mr. Muna } \\
\text { Sahoo }\end{array}$ & $\begin{array}{l}\text { 1. To study the financial } \\
\text { performance of SBI and } \\
\text { its associates } \\
\text { 2. To measure the impact } \\
\text { of NPAs on profitability } \\
\text { of SBI and its associates }\end{array}$ & $\begin{array}{l}\text { Statistical tools and } \\
\text { techniques such as } \\
\text { percentages, ratios, } \\
\text { Regression Model and } \\
\text { ANOVA are used in this } \\
\text { study. Statistical } \\
\text { packages like SPSS, } \\
\text { NumXL and XLSTAT are } \\
\text { used for the data } \\
\text { processing, Hypothesis } \\
\text { Testing(2004-05 to } \\
\text { 2016-17) }\end{array}$ & $\begin{array}{l}\text { 1.The amount of NPA has } \\
\text { increased from Rs. } 63629 \\
\text { million to Rs. } 969322 \\
\text { million whereas Net Profit } \\
\text { of SBI and its associates } \\
\text { have decreased from } \\
\text { Rs.56759 million to Rs.- } \\
13827 \text { million during the } \\
\text { period (2005-2017). } \\
\text { 2.Increase in Net NPA of } \\
\text { SBI and its associates do } \\
\text { not have any significant } \\
\text { impact on its net profit, } \\
\text { Return on Equity, Return } \\
\text { on Investment, Return on } \\
\text { Advances and Net Interest } \\
\text { Margin }\end{array}$ \\
\hline 6 & 2019 & $\begin{array}{c}\text { Bisma Afzal } \\
\text { Shah And } \\
\text { Khursheed } \\
\text { Ahmad Butt }\end{array}$ & $\begin{array}{l}\text { 1. To analyse the impact } \\
\text { of mergers and } \\
\text { acquisitions on the } \\
\text { operating performance of } \\
\text { the sample companies } 2 \text {. } \\
\text { To assess the impact of } \\
\text { mergers and acquisitions } \\
\text { on the financial } \\
\text { performance of the } \\
\text { sample companies } 3 \text {. To } \\
\text { analyse the impact of } \\
\text { mergers and acquisitions } \\
\text { on shareholder's return. }\end{array}$ & $\begin{array}{l}\text { Secondary data } \\
\text { collected from the } \\
\text { repository of Centre for } \\
\text { Monitoring Indian } \\
\text { Economy (CMIE). two } \\
\text { sample paired t-test } \\
\text { The financial ratios } \\
\text { used to analyse the } \\
\text { impact of a merger or } \\
\text { acquisition }\end{array}$ & $\begin{array}{l}\text { There are finally growth in } \\
\text { assets, reduction in } \\
\text { expenses, increase in } \\
\text { profitability margins, and } \\
\text { returns to the } \\
\text { shareholders }\end{array}$ \\
\hline 7 & 2019 & $\begin{array}{c}\text { S. } \\
\text { Narasimha } \\
\text { Chary, } \\
\text { Mohd Fasi }\end{array}$ & $\begin{array}{l}\text { 1. To analyse the Gross } \\
\text { NPA and Net NPAs of } \\
\text { selected public sector } \\
\text { banks 2. To assess the } \\
\text { trends of NPAs of } \\
\text { selected public sector } \\
\text { banks } \\
\text { 3. To analyse the impact } \\
\text { of non-performing assets } \\
\text { on the performance of }\end{array}$ & $\begin{array}{l}\text { The data is collected } \\
\text { from RBI publications, } \\
\text { annual reports of } \\
\text { banks, journals, official } \\
\text { records and other } \\
\text { published sources. }\end{array}$ & $\begin{array}{l}\text { 1. Unable to bring back the } \\
\text { bad loans or the } \\
\text { unproductive loans to the } \\
\text { banks, } \\
\text { 2. Non-performing assets } \\
\text { are seriously affecting the } \\
\text { banking system, resulting } \\
\text { in lower profitability, loss } \\
\text { and inconsistency in } \\
\text { financial performance of }\end{array}$ \\
\hline
\end{tabular}




\section{EPRA International Journal of Research and Development (IJRD)}

Volume: 6 | Issue: 2 | February 2021

- Peer Reviewed Journal

\begin{tabular}{|c|c|c|c|c|c|}
\hline & & & public sector banks & & $\begin{array}{l}\text { Indian banking system in } \\
\text { general and public sector } \\
\text { banks in particular. }\end{array}$ \\
\hline 8 & 2014 & $\begin{array}{c}\text { Abbas, } \\
\text { Hunjra, } \\
\text { Saeed, Ul- } \\
\text { Hassan, and } \\
\text { Ijaz }\end{array}$ & $\begin{array}{l}\text { 1. Examined the } \\
\text { performance of banks } \\
\text { during pre and post } \\
\text { M\&As in Pakistan by } \\
\text { evaluating } 10 \text { banks }\end{array}$ & & $\begin{array}{l}\text { 1. no significant } \\
\text { improvement in the banks' } \\
\text { financial performance } \\
2 . \text { a decrease in } \\
\text { profitability, efficiency, } \\
\text { liquidity, and leverage } \\
\text { ratios were also reported. }\end{array}$ \\
\hline 9 & 2012 & $\begin{array}{l}\text { Mahesh and } \\
\text { Prasad }\end{array}$ & $\begin{array}{l}\text { The financial } \\
\text { performance of these on } \\
\text { the post-merger and } \\
\text { acquisition, within 2005- } \\
2010 \text { period of time were } \\
\text { analysed }\end{array}$ & $\begin{array}{l}\text { Interest coverage, } \\
\text { dividend per share, net } \\
\text { profit margin, earning } \\
\text { per share, and return } \\
\text { on equity were the } \\
\text { variables used for the } \\
\text { study. Besides, paired } \\
\text { sample t-test }\end{array}$ & $\begin{array}{l}\text { The results show } \\
\text { insignificant } \\
\text { improvements in the } \\
\text { dependant variables } \\
\text { undertaken for the study }\end{array}$ \\
\hline 10 & 2016 & $\begin{array}{l}\text { Toumil } \\
\text { Hassen } \\
\text { Fakhri, } \\
\text { Amouri } \\
\text { Bilei, Touili } \\
\text { Nassim, } \\
\text { Hamidi } \\
\text { Faouzi } \\
\end{array}$ & $\begin{array}{l}\text { The profitability of } \\
\text { European private Banks }\end{array}$ & M.E and S.E Estimation & $\begin{array}{l}\text { Gain in Efficiency, increase } \\
\text { in long term profits in } \\
\text { terms of ROA and ROE. }\end{array}$ \\
\hline 11 & $\begin{array}{l}\text { Nov,20 } \\
10\end{array}$ & $\begin{array}{l}\text { Dr. Neena } \\
\text { Sinha, } \\
\text { Dr.K.P.Kaus } \\
\quad \text { hik, } \\
\text { Ms. Timcy } \\
\text { Chaudhary }\end{array}$ & $\begin{array}{lr}\text { Measuring } & \text { Post } \\
\text { and } & \text { Acquisition } \\
\text { Performance: } & \text { An } \\
\text { Investigation of Select } \\
\text { Financial } \\
\text { Organizations in India }\end{array}$ & $\begin{array}{l}\text { a. Sample Description } \\
\text { b. Wilcoxon Signed } \\
\text { Rank Test Methodology } \\
\text { c. Ratio analysis }\end{array}$ & $\begin{array}{l}\text { 1. More than half of the } \\
\text { merging firms showed } \\
\text { improved financial } \\
\text { performance in the post- } \\
\text { merger time period } \\
\text { 2. Significant change in } \\
\text { Debt- Equity Ratio }\end{array}$ \\
\hline 12 & $\begin{array}{l}\text { Aug } \\
2012\end{array}$ & $\begin{array}{l}\text { Gordon M. } \\
\text { Phillips } \\
\text { Alexei } \\
\text { Zhdanov }\end{array}$ & $\begin{array}{l}\text { R\&D and the incentives } \\
\text { from merger and } \\
\text { acquisition activity }\end{array}$ & $\begin{array}{l}\text { 1. Regression Analysis } \\
\text { 2. Acquisition Activity } \\
\text { and Industry Demand } \\
\text { and Supply } \\
\text { 3. Summary Statistics }\end{array}$ & $\begin{array}{l}\text { 1. Possibility of an } \\
\text { acquisition amplifies the } \\
\text { potential gains. } \\
\text { 2. merger and acquisition } \\
\text { activity strongly increases } \\
\text { firms' incentives to } \\
\text { conduct R\&D. }\end{array}$ \\
\hline 13 & $\begin{array}{l}\text { Dec } \\
2005\end{array}$ & $\begin{array}{l}\text { Myeong-Gu } \\
\text { Seo } \\
\text { N. Sharon } \\
\text { Hill } \\
\end{array}$ & $\begin{array}{l}\text { Understanding the } \\
\text { Human Side of Merger } \\
\text { and Acquisition }\end{array}$ & $\begin{array}{l}\text { Various theories and } \\
\text { frameworks }\end{array}$ & $\begin{array}{l}\text { There are ways to acquire } \\
\text { a firm other than a merger }\end{array}$ \\
\hline 14 & 2006 & $\begin{array}{c}\text { Susan } \\
\text { Cartwright } \\
\text { Richard } \\
\text { Schoenberg }\end{array}$ & $\begin{array}{l}30 \text { years of mergers and } \\
\text { acquisitions research: } \\
\text { recent advances and } \\
\text { future opportunities }\end{array}$ & Symposium & $\begin{array}{l}\text { 1. Executives are } \\
\text { undertaking acquisitions } \\
\text { driven by non-value } \\
\text { maximizing motives } \\
\text { 2. The prescriptions from } \\
\text { the academic research } \\
\text { have not reached the } \\
\text { practitioner } \\
\text { Community } \\
\text { 3. The research to date is }\end{array}$ \\
\hline
\end{tabular}




\section{EPRA International Journal of Research and Development (IJRD)}

Volume: 6 | Issue: 2 | February 2021

- Peer Reviewed Journal

\begin{tabular}{|c|c|c|c|c|c|}
\hline & & & & & incomplete in some way. \\
\hline 15 & & $\begin{array}{l}\text { Vassilis M. } \\
\text { Papadakis }\end{array}$ & $\begin{array}{l}\text { To investigate what } \\
\text { actually influences a } \\
\text { merger and acquisitions } \\
\text { (M\&As) successful } \\
\text { implementation. }\end{array}$ & $\begin{array}{l}\text { 1. Hypothesis testing } \\
\text { 2. Reliability and } \\
\text { validity testing }\end{array}$ & $\begin{array}{lr}1 . \quad \text { Comparing both } \\
\text { accounting and stock } \\
\text { return } \\
\text { 2. Testing more detailed } \\
\text { models of } \\
\text { performance. } & \\
\end{array}$ \\
\hline 16 & $\begin{array}{l}\text { Feb, } \\
2013\end{array}$ & $\begin{array}{l}\text { Stephen } \\
\text { P.Ferris } \\
\text { Narayanan } \\
\text { Jayaraman } \\
\text { Sanjiv } \\
\text { Sabherwal }\end{array}$ & $\begin{array}{l}\text { CEO Overconfidence and } \\
\text { International Merger and } \\
\text { Acquisition Activity }\end{array}$ & $\begin{array}{l}\text { Correlation } \\
\text { Regression } \\
\text { Poisson regression } \\
\text { Logistic Regressions }\end{array}$ & $\begin{array}{l}\text { 1. it is unclear whether } \\
\text { results obtained for U.S. } \\
\text { mergers will hold globally. } \\
2 \text {. overconfidence is } \\
\text { related to avariety of } \\
\text { merger characteristics. }\end{array}$ \\
\hline 17 & 2018 & $\begin{array}{l}\text { 1. Josua } \\
\text { Tarigan } \\
\text { 2. Alfonsis } \\
\text { Claresta } \\
\text { 3. Saarce } \\
\text { Elsye } \\
\text { Hatane }\end{array}$ & $\begin{array}{lr}\text { Analysis of } & \text { merger \& } \\
\text { acquisition } & \text { motives in } \\
\text { indonesian } & \text { listed } \\
\text { companies } & \text { through } \\
\text { financial } & \text { performance } \\
\text { perspective } & \end{array}$ & $\begin{array}{l}\text { Descriptives Statistics } \\
\text { Normality Test } \\
\text { Hypothesis Testing }\end{array}$ & $\begin{array}{l}\text { 1. companies undergoing } \\
\text { M\&A in the period of } 2009 \\
\text { until } 2012 \text { focus more on } \\
\text { growth strategy, shown by } \\
\text { the increase of liquidity } \\
\text { ratio. } \\
\text { 2. Solvency had also } \\
\text { increased significantly }\end{array}$ \\
\hline 18 & $\begin{array}{l}\text { Octobe } \\
\text { r } 2017\end{array}$ & $\begin{array}{l}\text { 1. V. M. } \\
\text { Lakhwani } \\
\text { 2. S. Tiwar } \\
\text { 3. S. Jauhar }\end{array}$ & $\begin{array}{l}\text { Mergers and acquisitions' } \\
\text { impact on financial } \\
\text { performance: } \\
\text { An evaluation with } \\
\text { perspective of time }\end{array}$ & EXPERIMENTAL & $\begin{array}{l}\text { 1. there is improvement in } \\
\text { the performance of } 18 \\
\text { companies after merger. } \\
\text { 2. ROA of only six } \\
\text { companies has shown } \\
\text { significant effect in terms } \\
\text { of improvement }\end{array}$ \\
\hline 19 & 2019 & $\begin{array}{l}\text { MAUREEN } \\
\text { KIMETTO }\end{array}$ & 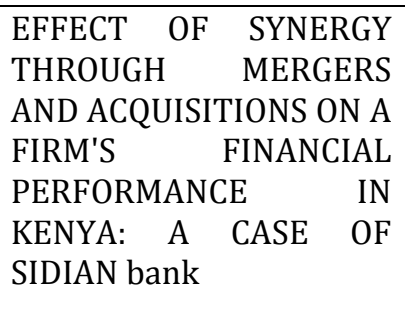 & $\begin{array}{l}\text { Correlation } \\
\text { Analysis of Variance } \\
\text { (ANOVA) Regression } \\
\text { Coefficients } \\
\text { case study }\end{array}$ & $\begin{array}{l}\text { 1. operation synergy had a } \\
\text { significant effect on the } \\
\text { financial performance of } \\
\text { bank. } \\
2 \text {. improved financial } \\
\text { performance in terms of } \\
\text { profitability for the banks }\end{array}$ \\
\hline 20 & 2011 & $\begin{array}{l}\text { Yelena V. } \\
\text { SMIRNOVA }\end{array}$ & $\begin{array}{l}\text { Motives for Mergers and } \\
\text { Acquisitions in the } \\
\text { Banking Sector of } \\
\text { Kazakhstan }\end{array}$ & Case study & $\begin{array}{l}\text { 1. motives for M\&A deals } \\
\text { in } 2009 \text { were different } \\
\text { from the prior. } \\
\text { 2. Some mergers and } \\
\text { acquisitions in Kazakhstani } \\
\text { banking sector were } \\
\text { driven by internal } \\
\text { impellent. }\end{array}$ \\
\hline
\end{tabular}

\section{OBJECTIVE OF THE STUDY}

The following are the objectives of the study:

1) To study the pre-merger and post-merger impact of merger and acquisition on the Non-performing assets of Industrial Credit \& Investment Corporation of India (ICICI Bank)
2) To study the pre-merger and post-merger impact of merger and acquisition on the profitability of Industrial Credit \& Investment Corporation of India (ICICI Bank).

3) To study the pre-merger and post-merger impact of merger and acquisition on the 


\section{EPRA International Journal of Research and Development (IJRD)}

Volume: 6 | Issue: 2 | February 2021

number of branches of Industrial Credit \& Investment Corporation of India (ICICI Bank).

\section{DATA AND METHODOLOGY}

Data for the study has been taken from Official website of ICICI Bank and analysed through the use of Excel-2016. Secondary data related to Non-performing Assets from Year 2006-2015 has been taken from ICICI Bank Database.

TABLE : 1 Showing the Gross and Net NPAs from 2005 to 2009

PRE-MERGER :

\begin{tabular}{|c|c|c|}
\hline Date & Gross NPA (in billion) & Net NPA (in billion) \\
\hline 31st March, 2005 & 34.32 & 19.83 \\
\hline 31st March, 2006 & 22.73 & 10.75 \\
\hline 31st March, 2007 & 41.68 & 20.19 \\
\hline 31st March, 2008 & 75.88 & 35.64 \\
\hline 31st March, 2009 & 98.03 & 46.19 \\
\hline Date & (\%) Change in Gross NPA & (\%) Change in Net NPA \\
\hline 31st March, 2005 & $-33.77 \%$ & $-45.79 \%$ \\
\hline 31st March, 2006 & $83.37 \%$ & $87.81 \%$ \\
\hline 31st March, 2007 & $82.05 \%$ & $76.52 \%$ \\
\hline 31st March, 2008 & $29.19 \%$ & $29.60 \%$ \\
\hline 31st March, 2009 & $-1.80 \%$ & $-15.54 \%$ \\
\hline
\end{tabular}

Graph 1 Showing Pre-merger analysis of ICICI Bank (Year 2005-2009)

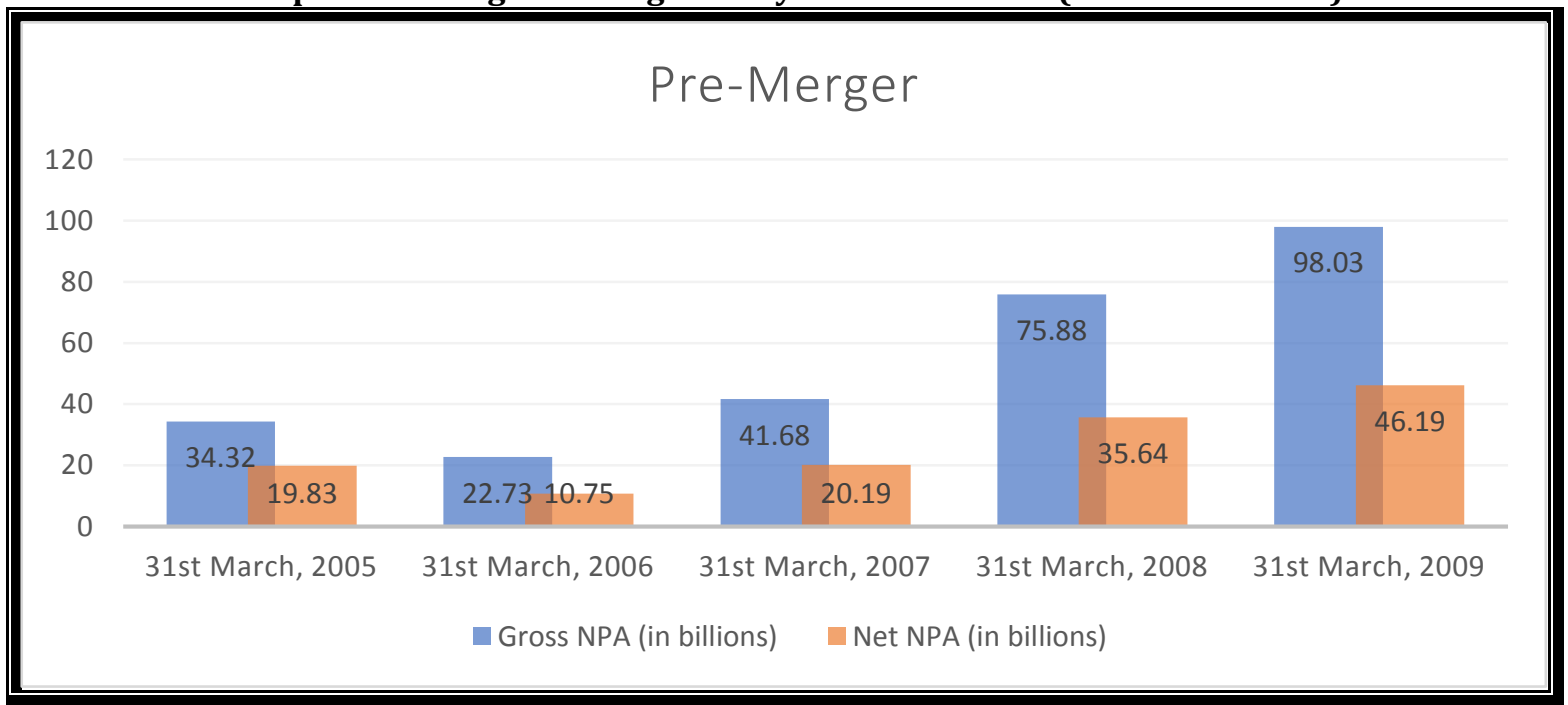

- ICICI Bank and Bank of Rajasthan were merged in the year. Therefore, the data of year 2010 is used in post merger analysis. 
SJIF Impact Factor 2021: 7.13| ISI I.F.Value:1.241| Journal DOI: 10.36713/epra2016

ISSN: 2455-7838(Online)

EPRA International Journal of Research and Development (IJRD)

Volume: 6 | Issue: 2 | February 2021

- Peer Reviewed Journal

TABLE : 2 Showing the Gross and Net NPAs from 2010 to 2015.

\begin{tabular}{|c|c|c|}
\hline Date & Gross NPA (in billions) & Net NPA (in billions) \\
\hline 31st March, 2010 & 96.27 & 39.01 \\
\hline 31st March, 2011 & 101.14 & 24.58 \\
\hline 31st March, 2012 & 95.63 & 18.94 \\
\hline 31st March, 2013 & 96.47 & 22.34 \\
\hline 31st March, 2014 & 105.54 & 33.01 \\
\hline 31st March,2015 & 152.42 & 63.25 \\
\hline Date & (\%) Change in Gross NPA & (\%) Change in Net NPA \\
\hline 31st March, 2010 & $5.06 \%$ & $-36.99 \%$ \\
\hline 31st March, 2011 & $-5.45 \%$ & $-22.95 \%$ \\
\hline 31st March, 2012 & $0.88 \%$ & $17.95 \%$ \\
\hline 31st March, 2013 & $9.40 \%$ & $47.76 \%$ \\
\hline 31st March, 2014 & $44.42 \%$ & $91.61 \%$ \\
\hline
\end{tabular}

Graph 2 showing post merger analysis of ICICI bank (Year 2010-2015)

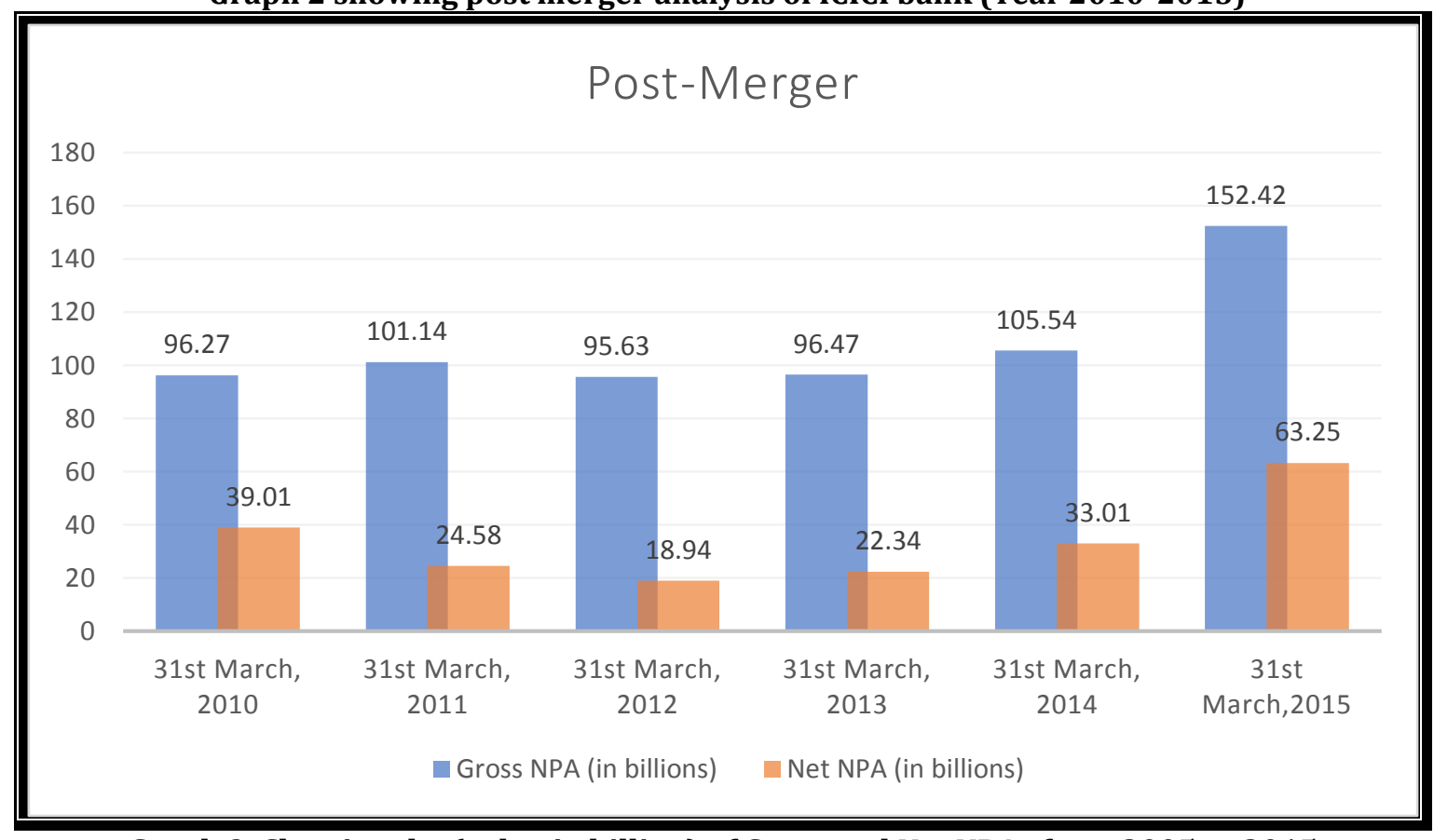

Graph 3: Showing the (value in billion) of Gross and Net NPAs from 2005 to 2015.

(c) 2021 EPRA IJRD | Journal DOI: https://doi.org/10.36713/epra2016 | www.eprajournals.com |72 | 


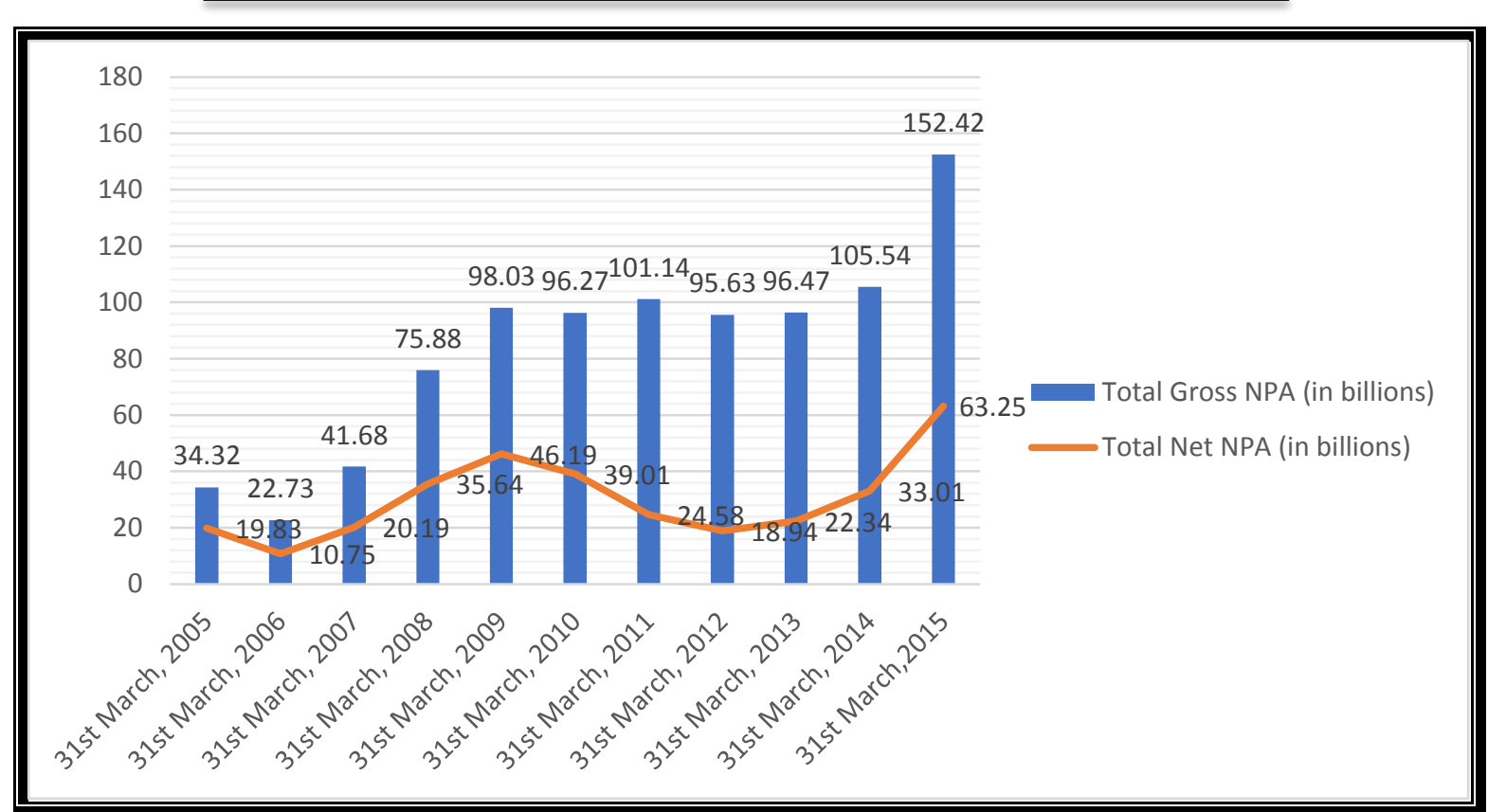

Combined Analysis of table $1 \& 2$ :

$>$ Table 1 shows Non-performing Assets of ICICI Bank in Absolute Terms whereas Table 2 shows Non-performing Assets in Relative Terms.

$>$ From Table 1, it is concluded that an increase in overall trend of Non-performing Assets of ICICI Bank was there except for the years 2006, 2010 and 2012. This three years have a negative ratio which means Non-performing Assets of this years has been decreased from the last year.

$>$ NPAs were decreased from 34.32 billion to 22.73 billion in Year 2005 and 2006.

$>$ Bank has 98.03 billion NPA in 2009 and in 2010 NPA were decreased to 96.27 billion.

$>$ In 2011 ICICI Bank has Gross NPA of 101.14 billion which were decreased to 95.63 billion which means bank has recovered approx. 6 billion of Gross NPAs.
$>$ IN 2015, ICICI has the highest NPA of 152.42 billion of Gross NPA which was 105.54 billion in the last year. An increase of approx. 47 billion Gross Non-performing Assets in just one year.

$>$ The Bank has approx. 50\% of their Gross Non-performing Assets as Net Nonperforming Assets.

$>$ ICICI Bank's NPA was less than 100 billion in each year before the merger but after the merger of both the banks NPAs crossed 100 billion and in 2015 it becomes 152 billion. But they are able to collect the bad loans and balance it.

$>$ After 2010, ICICI Bank has stable increase in NPA till 2014, but with increase in branches and products of ICICI Bank, increase in NPA is lower.

$>$ It is also concluded that ICICI Bank is efficient in coping up with the Nonperforming Assets.

TABLE 3 : Showing the value of share price (in INR) from 2005 to 2009.

Pre-Merger :

\begin{tabular}{|l|l|l|}
\hline Date & Share Price (in INR) & Earnings per Share (in INR) \\
\hline 31st March, 2005 & 401.48 & 27.6 \\
\hline 31st March, 2006 & 603.77 & 32.5 \\
\hline 31st March, 2007 & 809.34 & 34.8 \\
\hline 31st March, 2008 & 761.16 & 39.4 \\
\hline 31st March, 2009 & 338.45 & 33.8 \\
\hline
\end{tabular}

(SOURCE : NSE and https://www.icicibank.com/aboutus/annual.page) 
Graph 4 showing pre-merger analysis of ICICI bank (Year2005-2009)

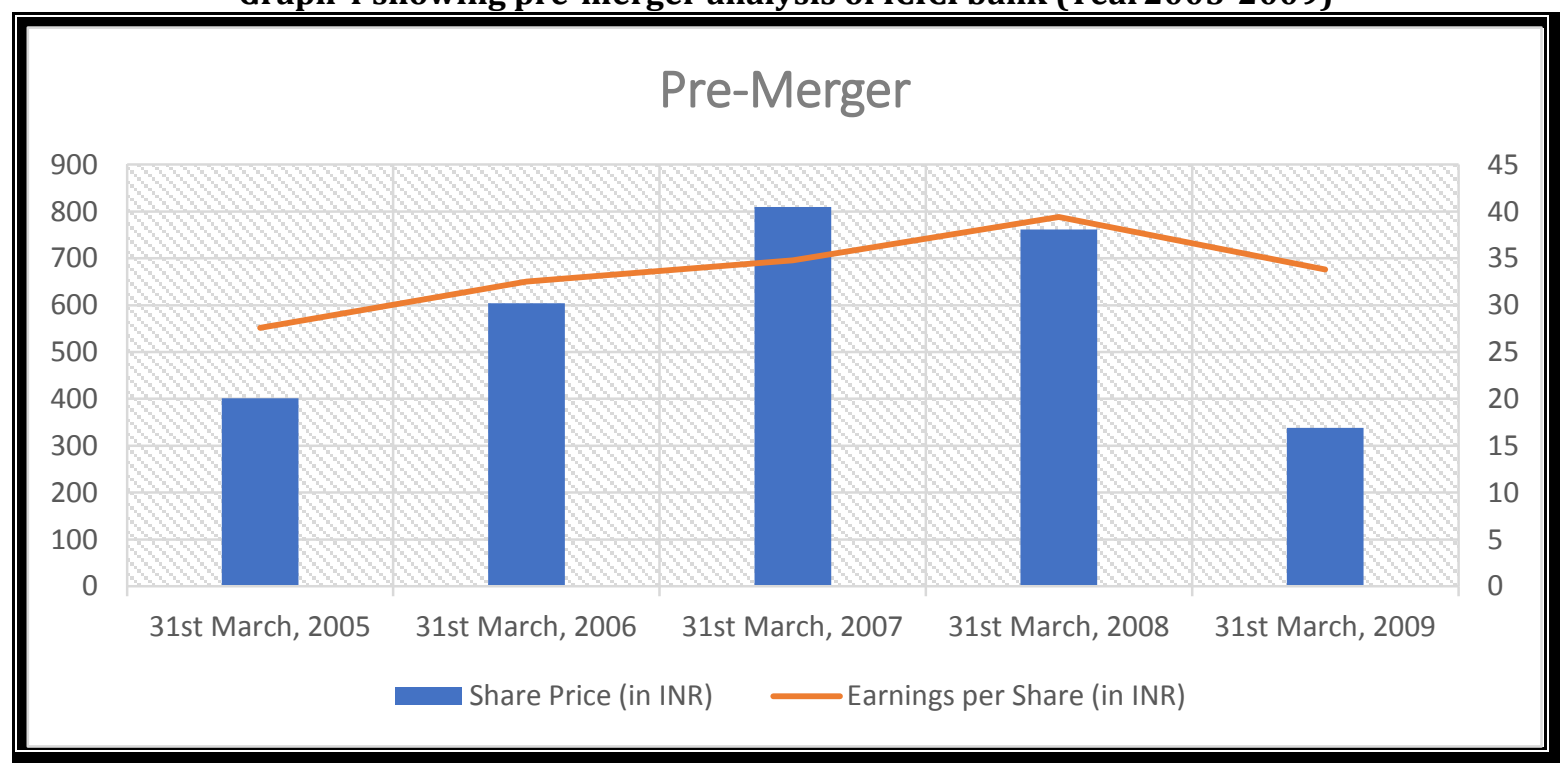

TABLE 4 : Showing the value of share price in INR from 2010 to 2015.

Post-Merger :

\begin{tabular}{|c|c|c|}
\hline Date & Share Price (in INR) & Earnings per Share (in INR) \\
\hline 31st March, 2010 & 950.92 & 36.14 \\
\hline 31st March, 2011 & $1,103.14$ & 45.27 \\
\hline 31st March, 2012 & 888.47 & 56.11 \\
\hline 31st March, 2013 & $1,049.70$ & 72.2 \\
\hline 31st March, 2014 & $1,231.68$ & 17 \\
\hline 31st March, 2015 & 319.63 & 19.32 \\
\hline
\end{tabular}

Graph 5: showing post-merger analysis of ICICI bank (Year 2010-2015)

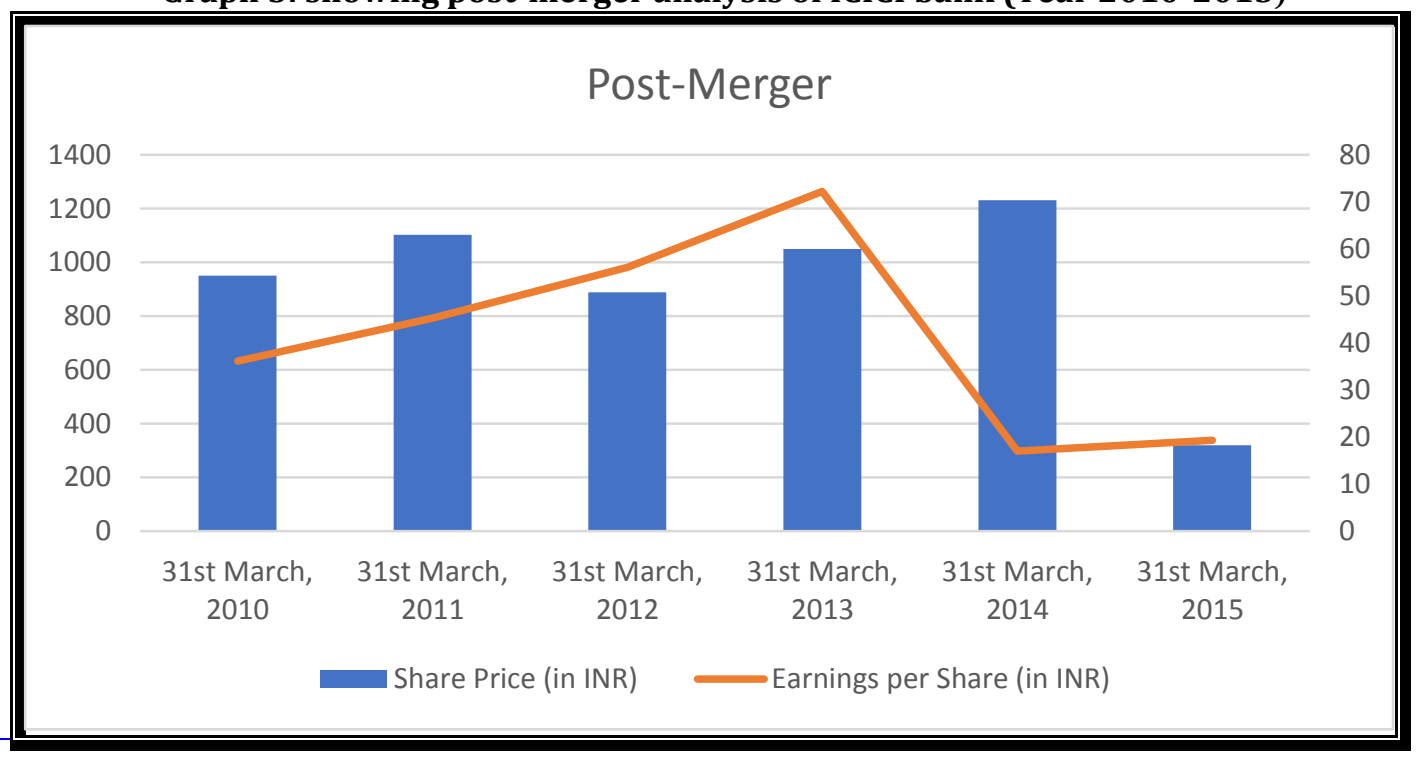

(c) 2021 EPRA IJRD | Journal DOI: https://doi.org/10.36713/epra2016 | www.eprajournals.com |74 | 


\section{EPRA International Journal of Research and Development (IJRD)}

Volume: 6 | Issue: 2 | February 2021

- Peer Reviewed Journal

Combined Analysis of table 3 and table 4:

$>$ Before 2010, ICICI has EPS which ranges between INR 20-40 and a continuous increment in EPS was reported except for the year 2009. In 2009, EPS was INR 33.8 which was decreased from INR 39.4 in 2008.

$>$ In 2010, EPS again increased and becomes INR 36.14 which again increased in Year 2011 to 45.27 INR.
EPS was decreased to INR 17 in year 2014 which was INR 72.2 in 2013 which was highest in all 11 years.

$>$ In 2014, ICICI Bank created a benchmark of INR 1,231.68 and in year 2015 Share price is at lowest (INR 319.63)

$>$ ICICI has many fluctuations in the share price over the years.

Graph 6: showing the value of Share price and Earning Per Share from 2005 to 2015.

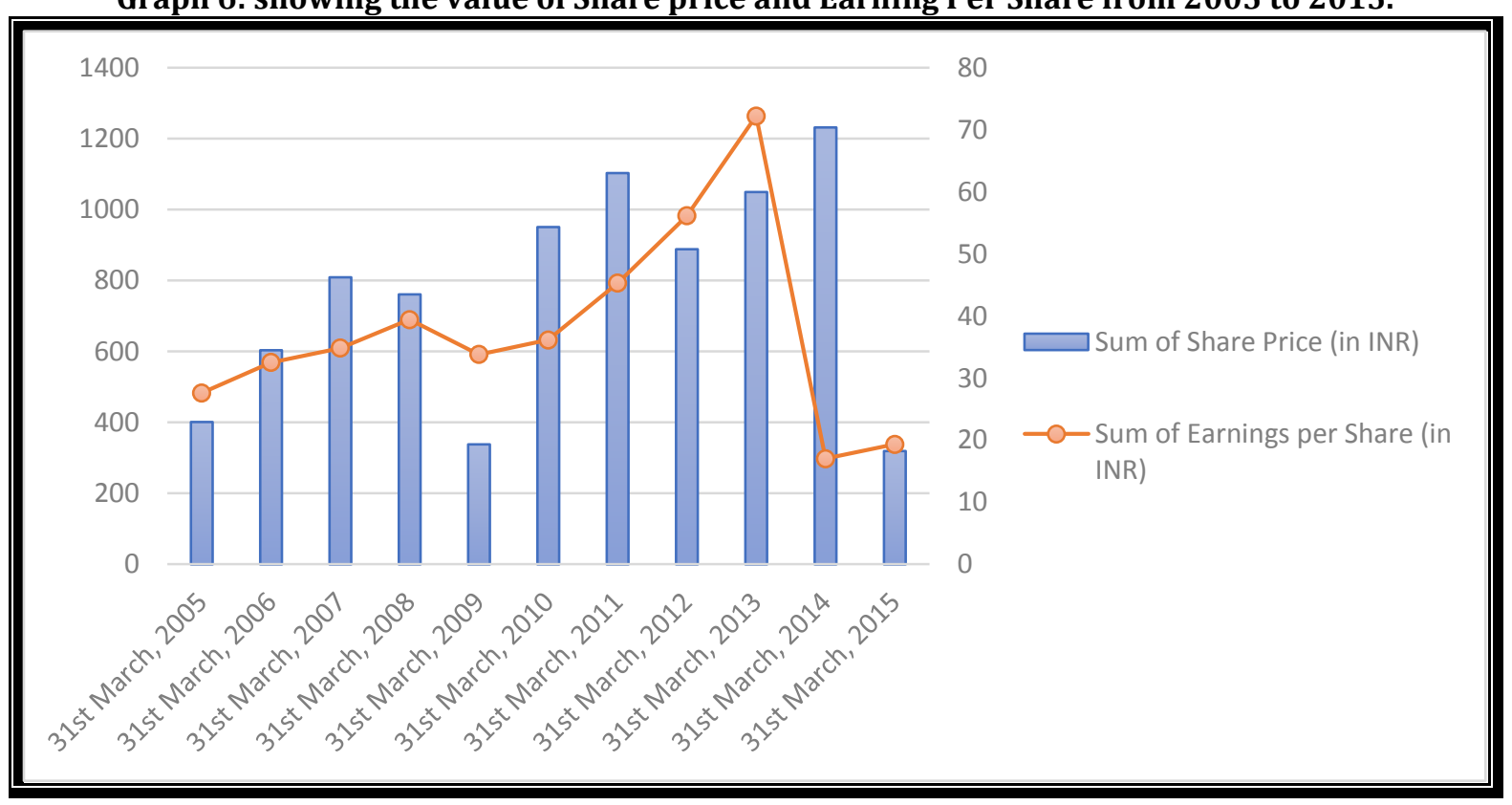

\section{CONCLUSION}

- ICICI Bank's NPA was less than 100 billion in each year before the merger but after the merger of both the banks, NPAs crossed 100 billion and in 2015 it becomes 152 billion. But they are able to collect the bad loans and balance it.

- After 2010, ICICI Bank has stable increase in NPA till 2014, but with increase in branches and products of ICICI Bank, increase in NPA is lower.

- Before 2010, ICICI has EPS which ranges between INR 20-40 and a continuous increase in EPS was there except for the year 2009. In 2009, EPS was INR 33.8, which was decreased from INR 39.4 in 2008.

- Since ICICI Bank was able to recover the bad loans which also shows that overall there was no huge impact of merger on EPS of the bank.

\section{BIBLIOGRAPHY}

1. Prasad V, K., \& Sahay, M. (2018). Analysis on Indian merger and acquisition in India with reference from 2005-2015. Http://Www.Ijpam.Eu/. https://ijpam.eu/

2. Natika Poddar. (2019, September). A Study on Mergers and Acquisition in India and Its Impact on Operating Efficiency of Indian Acquiring Company. Theoretical Economics Letters. http://www.scirp.org/journal/tel

3. Dr. Jyoti H. Lahoti. (2016, April). An Experiential Study of Mergers and Acquisitions in Indian Banking Sector. PARIPEX - INDIAN JOURNAL OF RESEARCH. https://www.ibpsexamadda.org.in/bankingawareness-49-mergers-and-acquisitions-ofbanks-7469/

4. KASHIRAMKA, S. M. I. T. A. (2012). An Empirical Analysis of Mergers \& Acquisitions in Indian Information Technology Sector and its Impact on Shareholders Wealth. https://www.BITSPILANI.com

5. Bharatkumar Soni, A. (2016). "Mergers and acquisitions in India and its impact on shareholders wealth." "Mergers and 
Acquisitions in India and Its Impact on Shareholders Wealth," 79-86. https://www.iosrjournals.org

6. Agrawal, A., Jaffe, J. F. \& Mandelker, G. N.: "The Post-Merger Performance of Acquiring Firms: a Re-examination of an Anomaly." The Journal of Finance, 47(4), 1992, pp-1605-1621

7. Narayan Kar, R., \& Soni, A. (2016). mergers and acquisitions in india: a strategic impact analysis for the corporate enterprises in the post liberalisation period. https://shaheedbhagatsingh.com

8. Tewari, P. D. D., \& S. Pradhan, P. R. (2020). splint International Journal of Professionals. Splint International Journal of Professionals, 2349-6045. http://www.splintjournal.in/

9. C.Y.-Y.L., \& Yu-Chen Wei. (2006). The Role of Business Ethics in Merger and Acquisition Success: An Empirical Study. The Role of Business Ethics in Merger and Acquisition Success: An Empirical Study, 95-109. https://springer.com

10. M. Papadakis, V. (1991). The role of broader context and the communication program in merger and acquisition implementation success. The Role of Broader Context and the Communication Program in Merger and Acquisition Implementation Success, 236-255. https://www.emerald.com/researchregister 